\title{
Characterization of Storage Sizing for an Off-Grid House in the US and the Netherlands
}

\author{
Diego Fernando Quintero Pulido ${ }^{1, *}$, Gerwin Hoogsteen ${ }^{1}$, Marnix V. ten Kortenaar ${ }^{2}$, \\ Johann L. Hurink ${ }^{1}$ (D), Robert E. Hebner ${ }^{3}$ and Gerard J. M. Smit ${ }^{1}$ \\ 1 Faculty of Electrical Engineering Mathematics Computer Science, University of Twente, P.O. Box 217, \\ 7500 AE Enschede, The Netherlands; g.hoogsteen@utwente.nl (G.H.); j.l.hurink@utwente.nl (J.L.H.); \\ g.j.m.smit@utwente.nl (G.J.M.S.) \\ 2 Dr Ten B.V., Rondweg 11M/N, 8091 XA Wezep, The Netherlands; marnix@drten.nl \\ 3 The Center for Electromechanics, The University of Texas at Austin, 10100 Burnet Rd, EME 133, \\ Austin, TX 78758, USA; r.hebner@cem.utexas.edu \\ * Correspondence: d.f.quinteropulido@utwente.nl; Tel.: +31-062-132-3089
}

Received: 30 November 2017; Accepted: 17 January 2018; Published: 23 January 2018

\begin{abstract}
This work uses experimental data to estimate the size of storage needed for an isolated off-grid household in two different regions (Austin, Texas, US, and Nunspeet, NL). In our study, an off-grid house is considered to be supplied with $100 \%$ renewable energy during the summer period, in which cooling demand is neglected, and a solar photovoltaic (PV) system and batteries are the main electrical energy providers. Based on results achieved with the DEMkit simulation package we can conclude that, in both cases, using a solar PV system and a Sea-Salt battery would have been sufficient to provide the necessary electricity without showing a blackout during the summer of 2016. The Austin household needs a solar PV system of $38 \mathrm{kWp}$ and storage of $452 \mathrm{kWh}$; in the case of Nunspeet, a solar PV system of $11.5 \mathrm{kWp}$ and storage of $90 \mathrm{kWh}$ is sufficient. Furthermore, using the DEMkit model, it is possible to determine an optimal value for the size of storage to half of the initial battery capacity ( $226 \mathrm{kWh}$ for Austin and $45 \mathrm{kWh}$ for Nunspeet) and still be able to provide enough power to cover the load demand of the households during the summer. In a second part, data of the solar PV system and load from Austin for one specific week was used to create data of a 'typical' but downscaled day. This day was used to determine the fluctuation of electricity for a real Sea-Salt battery for the considered off-grid scenario in Austin. The downscaling of the data was needed in order to have load values that fit to the size of the real battery. The tests show that the Sea-Salt battery under real electricity fluctuations is possibly adequate for off-grid scenarios.
\end{abstract}

Keywords: household; batteries; storage; sizing; islanded; off-grid; Sea-Salt battery

\section{Introduction}

Power generated from sustainable energy by, e.g., solar photovoltaic (PV) cells, is an ideal option for generating renewable power for households. However, the technology is constrained by weather conditions that influence energy generation. Due to this variation of energy production, energy-storage technologies (e.g., batteries) are an option worth considering for providing energy at times when it is needed but not supplied by renewable energy [1].

It is expected that, in the future, $100 \%$ off-grid houses will be an important and interesting asset in electrical grids [2]. They can achieve two goals: bringing flexibility to the grid and providing electricity to remote places. The first goal, if achieved, would entail that a house will only be disconnected from the grid and work in standalone mode during blackouts or maintenance periods [3,4]. This option depends on the reliability of the grid, which has been investigated by various authors. Shivakumar [5] researched the estimation of electricity interruption costs for households across the European Union 
(EU). It was found that the difference in cost resulting from interruptions in the electricity grid among EU member states is significantly large, ranging from $3.2 € / \mathrm{kWh}$ in Bulgaria to $15.8 € / \mathrm{kWh}$ in the Netherlands. The annual average for the value of lost load for the EU was calculated to be $8.7 € / \mathrm{kWh}$. In another study, Hanser and Leuken [6] investigated the use of a solar PV system and batteries to create an off-grid house in the US. They concluded that the use of houses as flexible assets in the grid can bring advantages in cases of blackouts. However, a solar PV system coupled with batteries still needs a backup power generator to secure electricity supply. Furthermore, Ardito and Procaccianti [7] researched the current status of smart grids in Europe. They show that the European situation is slowly changing given the priority to renewable energy with storage. However, the storage technologies still need to be evaluated in detail to be able to provide stable and reliable electricity for households. From these studies, it also can be concluded that the reliability of the grid could change in the short term. Furthermore, a 100\% off-grid house may also be an important asset for times of high energy demand. In such cases, it is possible that houses be controlled as flexible assets in the grid (to be disconnected/connected when needed) or as a backup in case of blackouts.

The second goal for 100\% off-grid houses is that they can give access to electricity in remote places that are still not connected to the grid. These cases are more notorious in developing countries. For example, Khodayar [8] investigated the current trends in microgrid systems for Africa and the impact on cities with low access to electricity, Hirmer and Guthrie [9] researched the benefits of off-grid energy appliances for places with low access to electricity, and Hashemi [10] analyzed a low-income tropical housing that could solve the problem of energy shortage in a house in Uganda. These studies support the view that renewable energy coupled with storage is the most likely technology to be implemented for the next years to power houses not connected to the grid. However, the feasibility to implement an off-grid electrical system for houses depends on the reliability of the technology and the local economy. In order to achieve a 100\% off-grid house, storage sizing is a crucial step. In the literature, storage sizing methods have been investigated. The focus has been in the development of algorithms for storage sizing for smart grids [11,12], the economic feasibility of batteries for large storage of renewables $[13,14]$, and hybrid renewable energy technologies combined with multiple storage systems $[15,16]$, to name a few. These studies concluded that storage sizing is important in order to ensure $100 \%$ off-grid scenarios for households. Furthermore, it is suggested that further research concentrate on showing that battery storage systems can be reliable during long periods of constant operation.

With respect to the battery system, a new battery call the Sea-Salt battery [17] has been chosen. This battery has been measured and tested at the University of Twente and will be used in a project sponsored by the Dutch Government. In this project, 24 households in the Gelderland province will be equipped with batteries. If the project runs successfully, the Sea-Salt battery may become an important asset for the implementation of $100 \%$ off-grid households. It is claimed that the battery manufacturing cost may be around 100 Euro/kWh and thereby may be lower than lithium-ion (400 Euro/kWh) [18] and comparable to lead acid batteries (120 Euro/kWh). The first lab test indicates that the Sea-Salt battery may be able to be $100 \%$ discharged without damage and that it has a lifetime of at least 7000 cycles. These characteristics of the Sea-Salt battery show that the technology may possibly play a role in the implementation of batteries in households in the future.

We set out to determine whether the combination of a solar PV system and Sea-Salt batteries is able to provide electrical power to a household for a summer period. For this, we use a distributed energy management methodology (DEM) for smart grids developed by the University of Twente [19-22]. We focus on two specific cases for which we investigate the energy consumption and solar PV production of households. The first household is located in Austin, Texas, US, and the second in Nunspeet, NL. In the case of Austin, the data for electricity consumption and solar PV production were collected from the Pecan Street database center [23] and in the case of Nunspeet, the data was measured locally. This data was then used to specify the electrical behavior of the households. Based on this 
data, the size of the Sea-Salt battery necessary to operate in a 100\% off-grid mode during the summer was determined.

This paper is organized as follows. First, some background information is given about the two households, the considered solar PV system, the Sea-Salt batteries, and the decentralized management methodology (DEMkit). Second, the experimental results are presented into two parts. Firstly, the analysis of the solar PV system and Sea-Salt batteries is given followed by the dynamic sizing/characterization of the solar PV system and the Sea-Salt battery to power the two different households. Secondly, we present an approach to test the Sea-Salt battery for off-grid application, in which a real battery is tested under scaled loads. The paper ends with some conclusions.

\section{Background Information}

In this section, the description of the considered households in Austin and Nunspeet are presented together with an example of the load and solar PV profiles of one day. Afterwards, the characteristics of the Sea-Salt battery are given followed by a detailed description of the used demand side management tool (DEMkit).

\subsection{Households Description}

To characterize the electric load of an off-grid house in Texas, data provided by Pecan Street Inc. in Austin (Austin, TX, USA), Texas, was used. This data is part of an ongoing study for smart grids and demonstration studies [23]. The study utilizes a testbed of 300 modern, green-built homes built after 2007, and 160 homes ranging from 10 to 92 years of age. The homes are equipped with electricity, gas, and water metering devices. Of the 300 homes in the study, 185 have rooftop solar PV panels, which are metered separately from the electricity demand. This database has been used in previous smart grid studies [24-28]. In the case of the household in Nunspeet, the experimental data was taken from a single household with characteristics similar to those of the household in Austin. The data was collected in situ with commercial metering devices.

Figure 1 shows the description of the resulting electricity layout of the selected households in Austin (Figure 1a) and in Nunspeet (Figure 1b). In the case of Austin, the household was selected by narrowing down the available data from the Pecan Street database to the household with the largest installed solar PV system and largest peak load and for which data for a whole year was available. Figure 1a shows that the selected Austin household has 148 solar PV panels of $280 \mathrm{Wp}$ installed in a grid-connected mode. A DC-to-AC inverter is used in order to deliver the electricity to the grid at $120 \mathrm{~V}$. The energy distributor is the company Austin Energy (Austin, TX, USA) [29]. Furthermore, the household has an electric hybrid-vehicle (EV), which is charged using the available electricity at the household (the electricity grid or the solar PV system). The EV, among all energy-consuming objects, has the highest energy consumption in the household with a power consumption of $3.7 \mathrm{kWp}$. In the case of Nunspeet (Figure 1b), the data was measured with the TED Pro Home real time with a home electricity monitor and an Energy Logger 4000 from the company Voltcraft (Hong Kong, China). All data was collected during the summer of 2016. The household has 48 solar PV panels connected to a DC-to-AC inverter in order to deliver the electricity to the grid at $230 \mathrm{~V}$.

An example of the data recorded for a day in June 2016 for the households in Austin and Nunspeet is presented in Figure 2. In the case of Austin (Figure 2a), the load distribution during the day has an average of $4.7 \mathrm{~kW}$. The maximum load is observed during the night $(12.9 \mathrm{~kW})$ and the lowest load during the early morning $(1.3 \mathrm{~kW})$. The maximum load may be produced due to an EV charging from 8:00 to 10:00 p.m., together with other appliances connected to the house (lights, TV, dishwasher, washing machine, etc.). The solar PV system generates electricity for approximately seven hours with an average production of $8.3 \mathrm{~kW}$. The solar PV peak produced is $34.9 \mathrm{~kW}$ between 12:00 to 2:00 p.m. 
Figure $2 \mathrm{~b}$ shows a one-day energy distribution of the household in Nunspeet. The load observed in the household has an average of $0.8 \mathrm{~kW}$, and a load peak of $5 \mathrm{~kW}$ is observed at around 7:00 a.m. The solar PV system installed in the household produces an average of $3.2 \mathrm{~kW}$ of electricity during the day and a peak production of $10 \mathrm{~kW}$ at around 10:00 a.m. In both cases, the trend of the load and solar PV production has a similar structure, although the total values are much larger in Austin. During the night and early morning periods, there is none or only a very low production of electricity from the solar PV system. At such times, the house is working fully on grid power. After the sun rises, the electrical load of the house is partly supplied by the solar PV system. However, the solar PV power increases and at some time is well beyond the load needed in the house. In this case, the solar PV surplus of electricity is injected to the grid. In order to create a $100 \%$ off-grid scenario, the solar PV excess of electricity may be stored in a battery instead of being transferred to the electrical grid. In order to perform the calculation of the size of storage needed for an off-grid scenario, the given energy profiles during the summer period of 2016 of these two households are used.

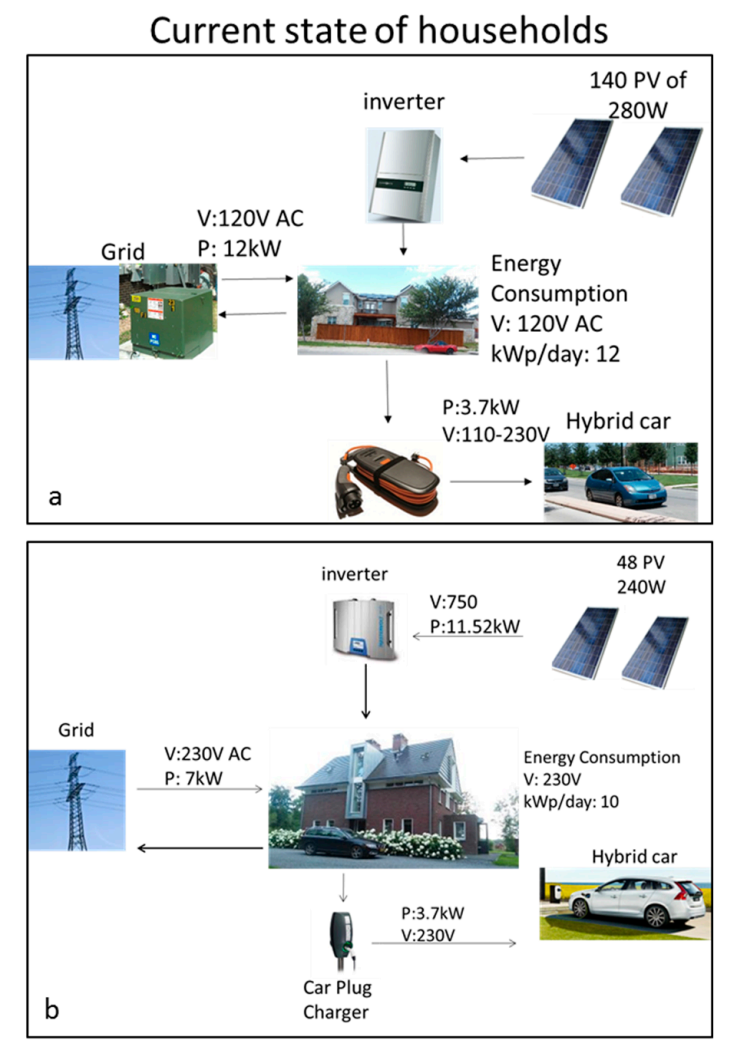

Figure 1. Sketch of the electric layout of a household: (a) Austin, Texas, US; (b) Nunspeet, NL.
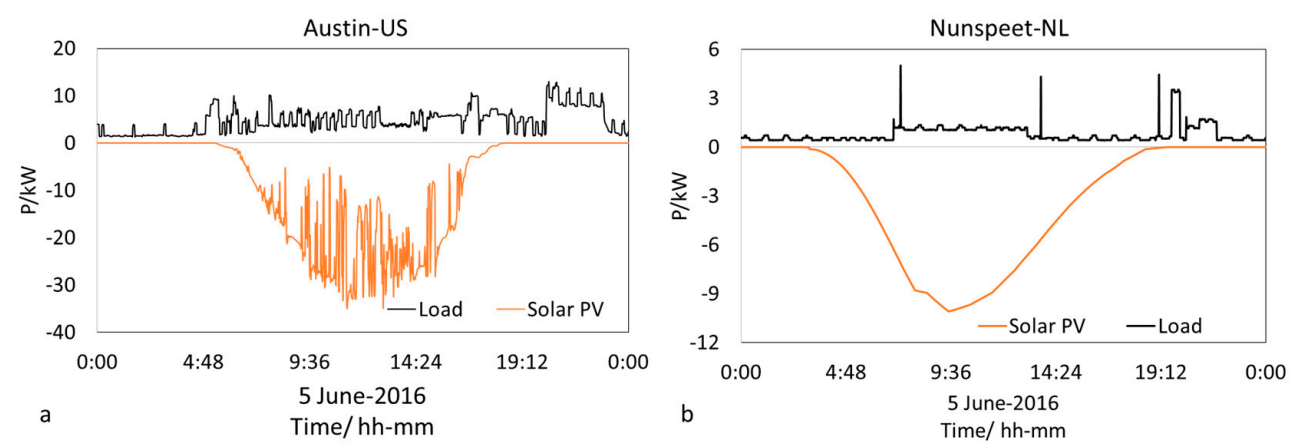

Figure 2. Example of load and solar PV daily profiles in June 2016: (a) Austin; (b) Nunspeet. 


\subsection{The Sea Salt Battery}

To determine the storage size needed for an off-grid household, we used as storage technology a Sea-Salt battery. The Sea-Salt battery may become an important for households that are a part of smart grids [30,31]. The battery is part of the ongoing research of the company Dr Ten (Wezep, The Netherlands) for the development of storage technologies, whereby the main focus has been on the development of the Sea-Salt battery [17] and the glycerol fuel cell [32,33]. The battery is made of carbon graphite and its electrolyte is based on sea salts (mostly $\mathrm{NaCl}$ ). This may make the Sea-Salt battery an environmentally friendly alternative. The charge per cell of the battery is on average about $1.9 \mathrm{~V}$ with a stable electrolyte (where hydrogen and oxygen evolution has not been noticed). The low voltage per cell reduces the possibilities of electrolysis, thus diminishing the risk of explosion. These characteristics make the Sea-Salt battery a good candidate for in-home storage of electricity.

In this study, we use the Sea-Salt battery in two ways. First, as an ideal storage device in the DEMkit model of the households where it is assumed that the device can be charged to $90 \%$ and discharge until $10 \%$ of its full capacity and second, as a real battery tested under scaled loads. In order to do this last part, the performance of the Sea-Salt battery was tested with a UBA5 charge/discharge battery analyzer from the company Vencon (North York, ON, Canada). The device is directly connected to the battery and run with the software Vencon-UBA Version 2017 with data recorded every five seconds.

\subsection{The DEMkit Simulator}

For the simulation study, the DEMKit simulation and demonstration toolkit was used [34]. The tool was developed at the University of Twente and is the successor of the previously developed TRIANA simulator [22]. DEMKit makes use of discrete time-series dynamic simulations using a bottom-up modeling approach. A library with device, grid, and control components is available in the tool. Generic device components are available that describe the behavior of a device and its operation constraints, such as the buffer capacity. An attached control implementation can optimize the operation of the device using these constraints. On the other side, an interface allows the devices to be connected to a physical grid model, such that it can be used to evaluate the effects of control actions on the delivered power quality. Using these components, households and other buildings can be modeled and connected to a physical (micro) grid model. On top of these physical components, a digital control system can be modeled. As a result, DEMKit can be used to perform simulations of cyber-physical systems, in which there is an interaction between the physical (devices and power grid infrastructure) and the digital (cyber) control system.

\section{Using DEMkit to Determine Storage Size}

The underlying model to study the feasibility of the envisioned Sea-Salt battery for an off-grid house consists of a battery storage system, household loads, and solar PV panels. Additionally, a control system is added that ensures that the power balance within the household is maintained. This results in the household model as shown in Figure 3. The static household load and PV production is provided using time series measurement data. Furthermore, an ideal battery model is used.

The simulated household power consumption is measured by the smart meter device model, which then communicates that information to the implemented HEMS (home energy management system). Based on the observation of the power consumption $\left(P_{\text {meter }}(t)=P_{\text {battery }}(t)+P_{\text {load }}(t)+P_{p v}(t)\right)$ at time $t$, the battery controller is instructed to inject or consume power to balance the household power consumption, i.e., to ensure no power is imported or exported in each time interval. Hence, the new power consumption of the battery is given by $P_{\text {battery }}(t+1)=P_{\text {battery }}(t)-P_{\text {meter }}(t)$. The battery controller verifies if this new power consumption is feasible, i.e., $P_{\text {min, battery }}(t) \leq P_{\text {battery }}(t) \leq$ $P_{\text {max,battery }}(t)$ and whether battery capacity constraints are met. More details of device models and 
control algorithms are given in [34]. The required capacity of battery storage system capacity can be determined from the data to ensure that the household can be supplied with the required power at all times.

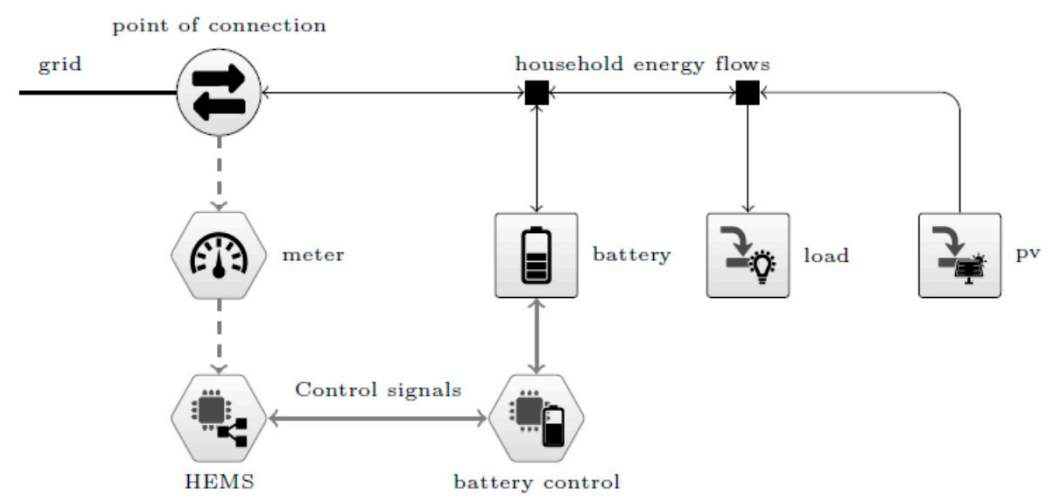

Figure 3. Diagram of the household model within DEMKit. The power consumption of the devices (rectangular blocks) result in a power surplus/deficit at the point of connection, which is measured by the meter. The HEMS and battery controller act on this information to balance the household power consumption.

\section{Results and Discussion}

In this section, we derive, based on the available data of the two households in the US and NL, the following. First, a simple baseline calculation for a possible storage size is given that is based on the assumption that the household should be able to be $100 \%$ off-grid for a short period of time (two days). In a second step, a simulation with the DEMkit tool is executed using the data of the summer period of 2016 and the baseline storage sizing. The results of this simulation lead to a minimum sizing of the storage needed for the households to be off-grid for the whole summer. Lastly, the results of the proof of concept for testing of a real Sea-Salt battery under scaled household loads and the solar PV system are given.

\subsection{Initial Sizing of the Storage}

To obtain an initial indication for the needed storage capacity, we use a common method described by Spiers [35]. This method is normally used by solar PV companies (e.g., [36]) for sizing batteries for off-grid scenarios. The method is shown in Equation (1), where $B_{C}$ is the battery capacity, $I_{B R}$ the total daily $A h$ required, $t_{R}$ the recommended reserve time, and $B_{U C}$ the percentage of battery useable capacity.

$$
\mathrm{B}_{\mathrm{C}}=\mathrm{I}_{\mathrm{BR}} \times \mathrm{t}_{\mathrm{R}} / \mathrm{B}_{\mathrm{UC}} .
$$

For the calculation, we assume that the battery is capable of fully support the household for a period of two days during the summer (also known as recommended reserved time); the two days refers to the average of continuous cloudy days. Therefore, we used the average consumption of the households during the summer $(4606 \mathrm{khW} /$ month in Austin and $918 \mathrm{kWh} / \mathrm{month}$ in Nunspeet). Additionally, the energy consumption of the households is corrected with a $15 \%$ factor due to losses in the AC-to-DC inverter. Furthermore, we assume that, during the two days, the battery does not receive any input via charging. We also assume that the battery has $80 \%$ useable capacity and a working voltage of $48 \mathrm{~V}$. The resulting values for sizing the battery are shown in Table 1. A battery of $452 \mathrm{kWh}$ for the household in Austin and a battery of $90 \mathrm{kWh}$ for the household in Nunspeet are needed to cover the average load demand of the households for two days. 
Table 1. Initial sizing of the battery based on the average power consumption of the households in Austin and in Nunspeet.

\begin{tabular}{|c|c|c|c|c|}
\hline Battery Design & Austin & & Nunspeet & Unit \\
\hline Households Avg. Energy Consumption during the summer & 4606 & & 918 & $\mathrm{KWh} /$ month \\
\hline $\mathrm{AC} / 0.85=\mathrm{DC}$ Correction Factor $(15 \%)$ & 5419 & & 1080 & KWh/month \\
\hline DC Consumption $\left(\mathrm{L}_{\mathrm{p}}\right)$ & 180.6 & & 36.0 & KWh/day \\
\hline Voltage battery system $V_{B}$ & & 48 & & $\mathrm{~V}$ \\
\hline Total daily $\mathrm{Ah}\left(\mathrm{I}_{\mathrm{BR}}=\mathrm{L}_{\mathrm{p}} / \mathrm{V}_{\mathrm{B}}\right)$ & 3.76 & & 0.750 & kAh/day \\
\hline Recommended reserve time $\left(t_{R}\right)$ & & 2 & & day \\
\hline Percentage of usable battery capacity $\left(\mathrm{B}_{\mathrm{UC}}\right)$ & & $80 \%$ & & -- \\
\hline Minimum battery capacity in $\mathrm{kAh}\left(\mathrm{B}_{C}=\mathrm{I}_{B R} \times \mathrm{t}_{R} / \mathrm{B}_{\mathrm{uc}}\right)$ & 9.41 & & 1.875 & kAh \\
\hline Minimum battery capacity in $\mathrm{kWh}$ & 452 & & 90 & $\mathrm{kWh}$ \\
\hline
\end{tabular}

\subsection{Storage Sizing Simulation}

The initial size for the storage is used as input for a simulation in order to research if this size of battery is enough to cover the load demand of the household in an off-grid scenario during the complete summer of 2016. These off-grid scenarios for the two households are depicted in Figure 4. The two households in Austin (Figure 4a) and in Nunspeet (Figure 4b) require a solar PV system connected to a DC-DC inverter in order to charge the batteries at a voltage of $48 \mathrm{~V}$. The battery and solar PV system require a DC-to-AC inverter to send the electricity from the battery to the household grid and power the appliances in the households. Within the simulation, all the generated solar PV energy is either stored in the Sea-Salt battery, injected to the household electricity grid, or the surplus is curtailed.

(a)
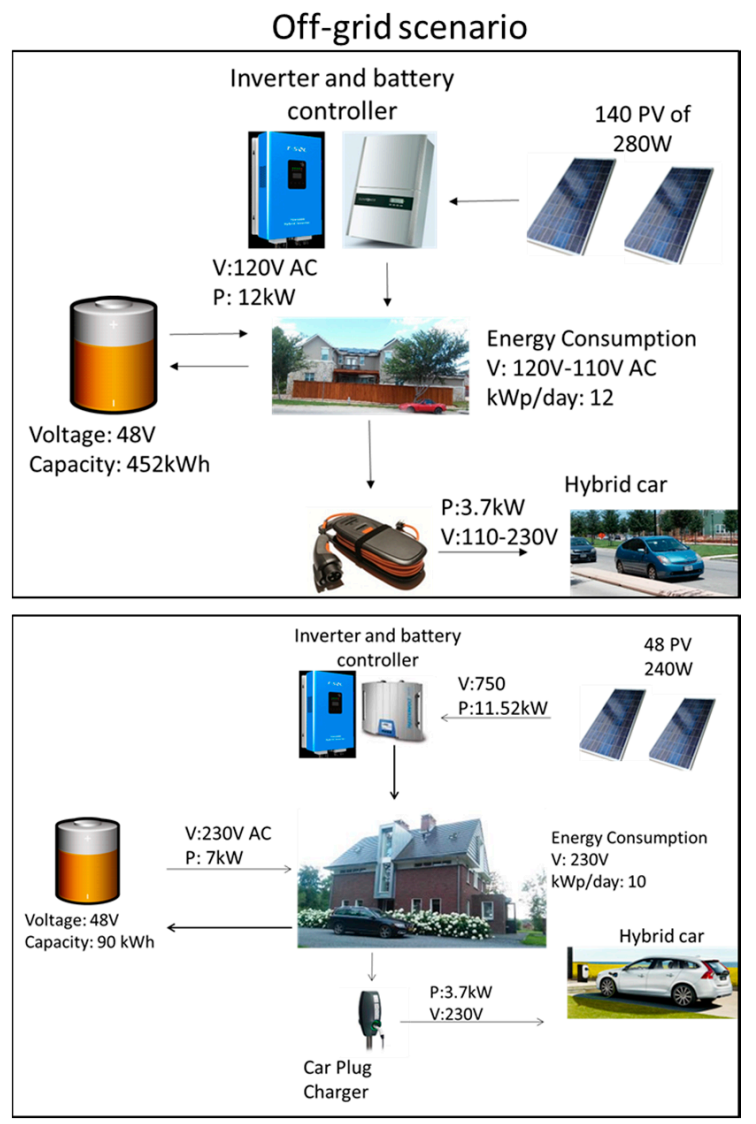

Figure 4. Description of electricity distribution for off-grid scenario: (a) Austin; (b) Nunspeet. 
In the simulation with DEMkit, we used the available solar PV profiles (like the one in Figure 2) as input, the available household profiles, and the battery with a capacity as calculated in Section 3.1. Within the simulation, the battery is charged with the excess of solar energy not needed for supplying the household and discharged during the periods where insufficient solar production is available to power the appliances in the households. The output of the simulation is the resulting state-of-charge profile of the battery, which refers to the energy content (EC) of the battery in kWh.

Figure 5 shows the input profiles for the simulation and the resulting EC profile of the battery during the summer of 2016. In the case of Austin, the profiles of the solar PV system and load are shown in Figure 5a. The average load of the household is $4.6 \mathrm{~kW}$ with a peak load of $14.6 \mathrm{~kW}$ and the average solar PV energy generated is $7.7 \mathrm{~kW}$ with a peak production of $38.5 \mathrm{~kW}$. Figure $5 \mathrm{~b}$ shows the profile behavior of the Sea-Salt battery that is connected to the solar PV system for the off-grid household scenario. The results show that the battery average EC is $421 \mathrm{kWh}$ with a minimum EC of $275.7 \mathrm{kWh}$. Moreover, since the battery EC is always above the lowest possible value of $90 \mathrm{kWh}$ ( $20 \%$ of the capacity) during the entire studied period, a full discharge of the battery does not occur.

In the case of the household in Nunspeet, the average load during the period is $0.9 \mathrm{~kW}$ and the peak load is $9.8 \mathrm{~kW}$. Furthermore, the average solar PV energy generated is $1.7 \mathrm{~kW}$ with a peak production of $10.4 \mathrm{~kW}$ (see Figure $5 \mathrm{c}$ ). The battery behavior for the off-grid household in Nunspeet is shown in Figure 5d. The battery had an average EC of $82.4 \mathrm{kWh}$ and the minimum EC observed is $52.9 \mathrm{kWh}$. Moreover, the minimum possible EC of $19 \mathrm{kWh}$ is not reached during the entire summer.
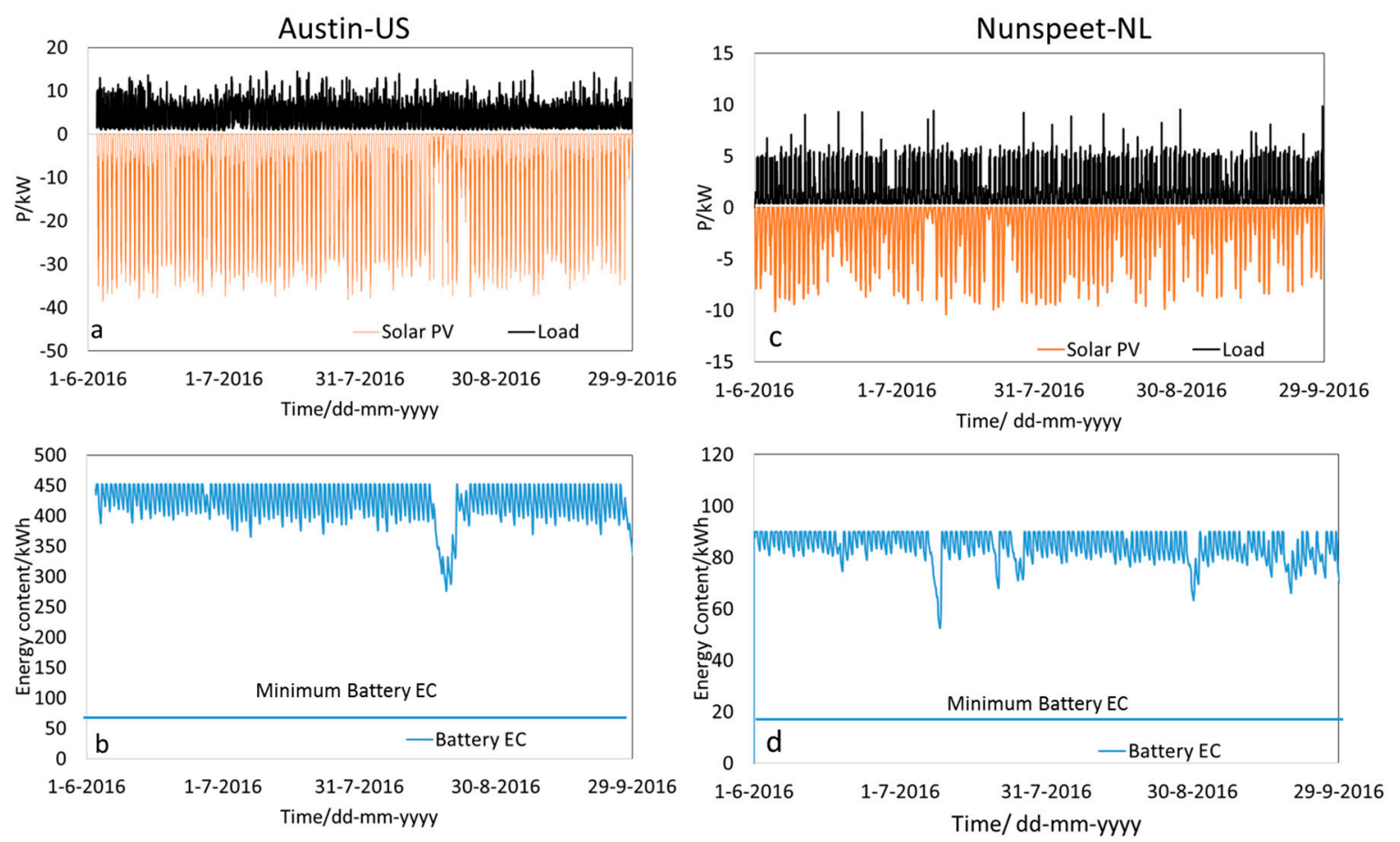

Figure 5. Profiles resulting from simulating a household for the summer of 2016 using the initial capacity for the storage in (a) Austin (solar PV energy and load); (b) Austin (battery EC); (c) Nunspeet (solar PV energy and load); and (d) Nunspeet (battery EC).

In both cases, the modeled battery is able to provide $100 \%$ of the dynamic power deficit to the households during the summer of 2016 (June-September 2016). In Austin, a battery of $452 \mathrm{kWh}$ is necessary, and a battery of $90 \mathrm{kWh}$ is needed in Nunspeet, and this is possible only with the available solar PV system. However, Figure 5 also shows that the chosen battery size is large enough to cover the household's electricity demand (the maximum discharge of the Sea-Salt battery is not reached). Based on the given results, a minimal battery size needed to create the $100 \%$ off-grid scenario can be 
estimated. For these values, we chose $226 \mathrm{kWh}$ for Austin and $45 \mathrm{kWh}$ for Nunspeet. The results of the simulation of DEMkit using this capacity are presented in Figure 6.
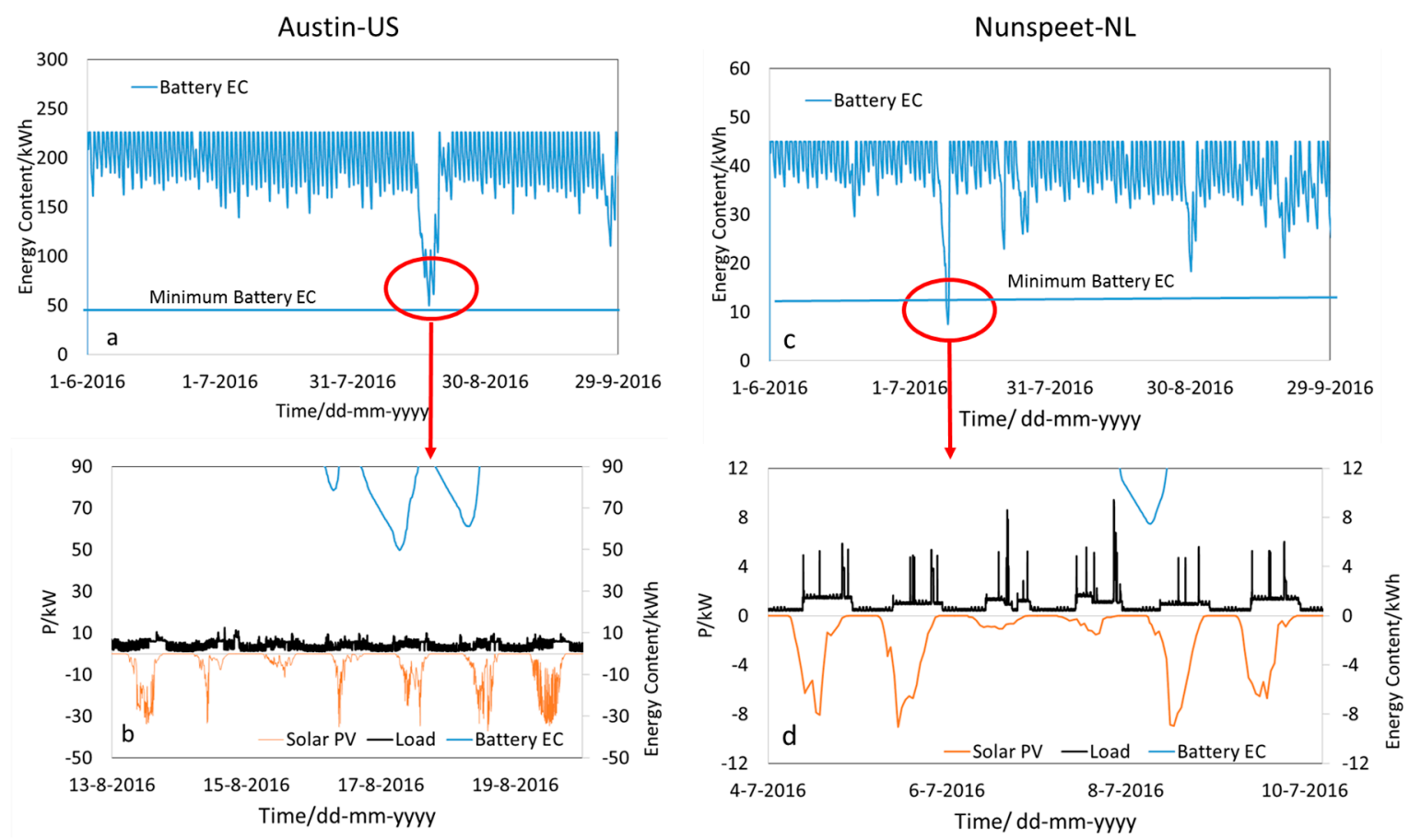

Figure 6. Profiles of a household modeled with a solar PV system and a reduced storage size for the summer of 2016. (a) Complete summer in Austin; (b) Week with lowest solar PV production in Austin;

(c) Complete summer in Nunspeet; (d) Week with lowest solar PV production in Nunspeet.

In the case of Austin, the simulation results for a battery capacity of $226 \mathrm{kWh}$ is presented in Figure 6a. The results indicate an average EC of $192 \mathrm{kWh}$. Furthermore, the minimum EC recorded is $49.8 \mathrm{kWh}$. This value is shown during the week with the lowest solar PV production (13-19 August). Figure $6 \mathrm{~b}$ shows the profiles in the week with low solar PV energy in which the battery has the deepest discharge. In this week, the average solar PV production is only $4.4 \mathrm{~kW}$ with a peak of $37 \mathrm{~kW}$. Moreover, the load in this week has an average of $3.9 \mathrm{~kW}$ and a peak of $12.5 \mathrm{~kW}$.

For the Nunspeet case, the results for the reduced battery size are presented in Figure 6c. The average battery EC is $38.3 \mathrm{kWh}$. Moreover, a discharge of the battery below the minimum allowed EC is not observed during the studied period. The minimum observed EC is $9.8 \mathrm{kWh}$. This value occurs during the week with the lowest solar PV production (4-10 July; Figure $6 \mathrm{~d}$ shows the profiles in this week). Here, the average solar PV production is $1.5 \mathrm{~kW}$ with a peak of $9.0 \mathrm{~kW}$ and the load has an average of $0.97 \mathrm{~kW}$ with a peak of $9.4 \mathrm{~kW}$.

The results for the reduced size of the battery show that these capacities are sufficient to provide the necessary power to maintain the households $100 \%$ off-grid without causing a shortage of electricity. Summarizing, the household in Austin requires a battery of $226 \mathrm{kWh}$ and the household in Nunspeet a battery of $45 \mathrm{kWh}$. Note that these values are half of the capacities resulting from the method use in Section 3.1 (see Figure 5b,d). This indicates that in case a solar PV system is available, a different approach should be developed. Such an approach should take into account the average or minimum amount of PV production in the considered period that the battery has to bridge.

\subsection{Proof of Concept for Testing a Sea-Salt Battery under Scaled Load}

The testing of batteries under scaled loads is a method using available electricity data to observe the behavior of a (smaller-sized) battery by using electricity inputs/outputs with the same variations 
as the available electricity data. This method may offer a less expensive alternative than a full-sized battery for testing. For the scenarios considered in this research, we use a small Sea-Salt battery as an example. This section is presented in two parts. First, some standard tests are performed to observe the battery capacity (performance under discharge) of the given Sea-Salt battery; secondly, the behavior of the Sea-Salt battery is tested under scaled loads using data from one week of summer from the household in Austin.

Figure 7a shows the voltage behavior of a single cell Sea-Salt battery using different constant discharge loads and Figure $7 \mathrm{~b}$ shows multiple Sea-Salt batteries connected to form a battery pack. In the example in Figure 7a, the battery was charged with a constant current of $250 \mathrm{~mA}$ for $10 \mathrm{~h}$. Furthermore, different discharged rates $(C / 10-C / 5)$ were tested (C-rate corresponds to the maximum capacity of the battery divided by the desired discharge time). The results of the experiment are presented in detail in Table 2 . The minimum and maximum current efficiency of the battery are $81 \%$ $(\mathrm{C} / 10)$ and $93 \%(\mathrm{C} / 5)$, respectively. The OCP (open circuit potential) where no load is applied had an average of $1.74 \mathrm{~V}$ at the different $\mathrm{C}$ rates tested. The average discharge voltage had a minimum value of $1.36 \mathrm{~V}$ at $\mathrm{C} / 5$ and a maximum average voltage of $1.5 \mathrm{~V}$ at $\mathrm{C} / 10$. In all of the experiments, the battery was discharged until the output voltage was reduced by $0.2 \mathrm{~V}$. When comparing the Sea-Salt battery power output for the different discharge rates, it was observed that the battery has the highest power output at $\mathrm{C} / 9(3.29 \mathrm{Wh})$ and the lowest at $\mathrm{C} / 5(3.18 \mathrm{Wh})$. This effect is possibly related to battery internal resistances (ohmic losses), measuring equipment (cables, and distance of the battery with the measuring device), and self-discharge effects. The presented results for the given battery show that the Sea-Salt battery has potential to be used in scenarios in which long periods with discharge load are present (such as for off-grid households with a solar PV system).

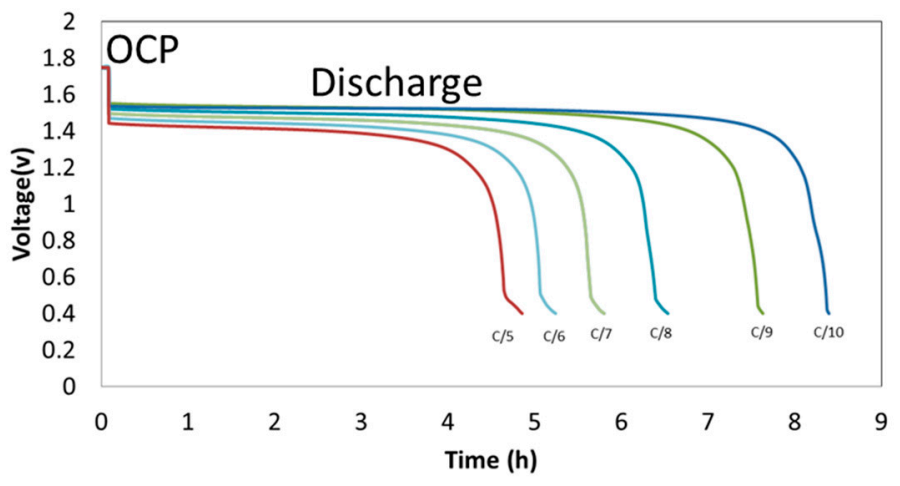

a

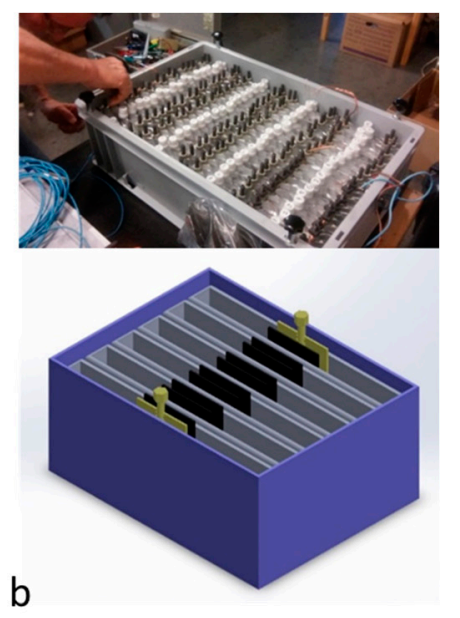

b

Figure 7. (a) Voltage behavior of the Sea-Salt battery in one single cell at different C-rates; (b) Example of multiple Sea-Salt batteries connected to form a stack.

To test this, a Sea-Salt battery was tested under scaled loads constructed using the data from Austin. The goal of this test was to observe the changes that the battery undergoes under real loads, using only low power equipment. In order to do the test, the following steps were executed. First, a Sea-Salt battery was constructed and configured with $4 \mathrm{Wh}$ and $6 \mathrm{~V}$ nominal voltage. Second, the household load and the solar PV system of Austin was scaled down 10,000 times. Lastly, the battery was connected to a UBA5 battery testing equipment in order to simulate the charge/discharge operation of the battery for the household in Austin. In the scaled period, one day is simulated every three hours, giving the possibility to test four days of modeled off-grid conditions in one day. Figure 8 shows the profiles of the used input and the resulting profile of the battery. Note that, in this figure, the battery voltage is the indicator of the battery SoC (the Sea-Salt battery is 100\% charged when the voltage reaches $7.9 \mathrm{~V}$ and fully discharges when the battery voltage is $5.1 \mathrm{~V}$ ). 


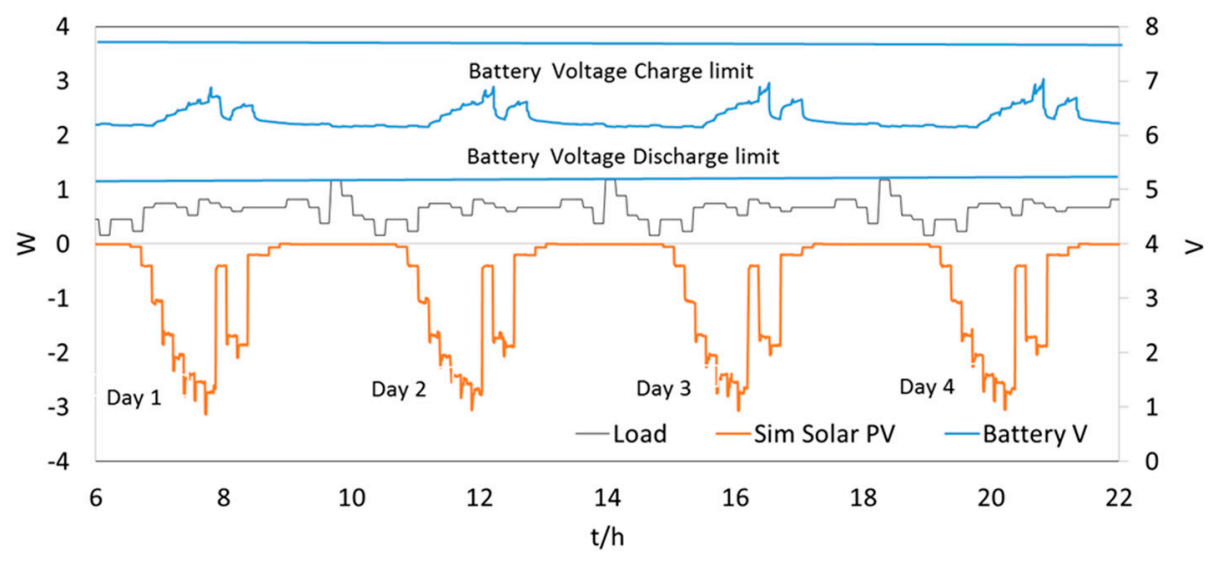

Figure 8. Profiles testing of the Sea-Salt battery under scaled loads.

Table 2. C-rate results for a single cell Sea-Salt battery.

\begin{tabular}{ccccccc}
\hline C Rate & Charge Ah & Discharge Ah & $\begin{array}{c}\text { Current } \\
\text { Efficiency \% }\end{array}$ & OCP & $\begin{array}{c}\text { V Discharge } \\
\text { Avg. }\end{array}$ & Capacity Wh \\
\hline $\mathrm{C} / 10$ & 2.49938 & 2.03699 & $81 \%$ & 1.7453 & 1.5026 & 3.060781174 \\
$\mathrm{C} / 9$ & 2.49961 & 2.21013 & $88 \%$ & 1.7406 & 1.4889 & 3.290662557 \\
$\mathrm{C} / 8$ & 2.49923 & 2.26647 & $91 \%$ & 1.7456 & 1.4345 & 3.251251215 \\
$\mathrm{C} / 7$ & 2.49909 & 2.27749 & $91 \%$ & 1.7412 & 1.4087 & 3.208300163 \\
$\mathrm{C} / 6$ & 2.49913 & 2.28835 & $92 \%$ & 1.7345 & 1.3867 & 3.173254945 \\
$\mathrm{C} / 5$ & 2.49942 & 2.33479 & $93 \%$ & 1.7456 & 1.3656 & 3.188389224 \\
\hline
\end{tabular}

The results show that the load of the simulated household has a maximum value of $1 \mathrm{~W}$, with an average consumption of $0.6 \mathrm{~W}$, and the simulated solar PV system has a maximum energy production of $3 \mathrm{~W}$ with an average of $1.5 \mathrm{~W}$. The Sea-Salt battery profile shows a similar shape during the four simulated days. In addition, the voltage charge limit was not reached, nor was the voltage discharge limit. Thus, the experiment shows that the battery can deal with the offered profiles without being fully charged or fully discharged during the tested period. The minimum voltage observed was $6.1 \mathrm{~V}$, and the highest charge voltage was $7 \mathrm{~V}$. Although this method may give an indication of the battery behavior for off-grid scenarios in households, more research should be performed so that a more reliable conclusion of the potential of the Sea-Salt battery can be made.

\section{Conclusions}

Based on the experimental data collected in the summer of 2016 for the households in Austin and Nunspeet, it is concluded that during this period a PV installation combined with a battery may provide the necessary electricity for a $100 \%$ off-grid household without showing a blackout. The Austin household needs a solar PV system of $38 \mathrm{kWp}$ and a storage of $226 \mathrm{kWh}$, and the Nunspeet household needs a solar PV system of $11.5 \mathrm{kWp}$ with a storage of $45 \mathrm{kWh}$. To achieve these results, the DEMkit simulation tool was used. Furthermore, solar PV and load data for one week was used to create down-scaled data for one day and was then used to test if a real Sea-Salt battery would be able to deal with the fluctuation of electricity for the considered off-grid scenario in Austin. The results of this test indicate that the Sea-Salt battery may have the potential to be used for such off-grid applications, although more tests are needed to support this conclusion. A further conclusion of the research is that the presented down-scaling method may be a useful approach for battery testing under real electricity fluctuations.

Acknowledgments: This work was sponsored by the STW-I-Care 11854 project and Dr Ten BV, in The Netherlands as part of its ongoing development research and demonstration of storage systems for smart grid integration. Special thanks to the University of Austin, Texas, and Alliander for providing their support during this research. 
Author Contributions: Diego Fernando Quintero Pulido, performed the simulations and prepared the manuscript as the first author. Gerwin Hoogsteen designed the DEMkit for the simulated storage sizing and contributed to the manuscript. Marnix V. ten Kortenaar coordinated the research of the Sea-Salt Battery. Johann L. Hurink discussed the simulation results and corrected the paper. Robert E. Hebner give advice and support for the data collected in Austin-TX-USA and Gerard J. M. Smit is the professor leader of the project. All authors read and approved the publication.

Conflicts of Interest: The authors declare no conflict of interest.

\section{References}

1. Parra, D.; Swierczynski, M.; Stroe, D.I.; Norman, S.A.; Abdon, A.; Worlitschek, J.; O’Doherty, T.; Rodrigues, L.; Gillott, M.; Zhang, X.; et al. An interdisciplinary review of energy storage for communities: Challenges and perspectives. Renew. Sustain. Energy Rev. 2017, 79, 730-749. [CrossRef]

2. Olabi, A.G. Renewable energy and energy storage systems. Energy 2017, 136, 1-6. [CrossRef]

3. Mohler, D.; Sowder, D. Energy Storage and the Need for Flexibility on the Grid. In Renewable Energy Integration; Elsevier: Amsterdam, The Netherlands, 2017; pp. 309-316, ISBN 9780128095928.

4. Ghafoor, A.; Munir, A. Design and economics analysis of an off-grid PV system for household electrification. Renew. Sustain. Energy Rev. 2015, 42, 496-502. [CrossRef]

5. Shivakumar, A.; Welsch, M.; Taliotis, C.; Jakšić, D.; Baričević, T.; Howells, M.; Gupta, S.; Rogner, H. Valuing blackouts and lost leisure: Estimating electricity interruption costs for households across the European Union. Energy Res. Soc. Sci. 2017, 34, 39-48. [CrossRef]

6. Hanser, P.; Lueken, R.; Gorman, W.; Mashal, J. The practicality of distributed PV-battery systems to reduce household grid reliance. Util. Policy 2017, 46, 22-32. [CrossRef]

7. Ardito, L.; Procaccianti, G.; Menga, G.; Morisio, M. Smart Grid Technologies in Europe: An Overview. Energies 2013, 6, 251-281. [CrossRef]

8. Khodayar, M.E. Rural electrification and expansion planning of off-grid microgrids. Electr. J. 2017, 30, 68-74. [CrossRef]

9. Hirmer, S.; Guthrie, P. The benefits of energy appliances in the off-grid energy sector based on seven off-grid initiatives in rural Uganda. Renew. Sustain. Energy Rev. 2017, 79, 924-934. [CrossRef]

10. Hashemi, A. Arman Climate Resilient Low-Income Tropical Housing. Energies 2016, 9, 468. [CrossRef]

11. Fossati, J.P.; Galarza, A.; Martín-Villate, A.; Fontán, L. A method for optimal sizing energy storage systems for microgrids. Renew. Energy 2015, 77, 539-549. [CrossRef]

12. Schneider, M.; Biel, K.; Pfaller, S.; Schaede, H.; Rinderknecht, S.; Glock, C.H. Using inventory models for sizing energy storage systems: An interdisciplinary approach. J. Energy Storage 2016, 8, 339-348. [CrossRef]

13. Grantham, A.; Pudney, P.; Ward, L.A.; Whaley, D.; Boland, J. The viability of electrical energy storage for low-energy households. Sol. Energy 2017, 155, 1216-1224. [CrossRef]

14. Bruch, M.; Müller, M. Calculation of the Cost-effectiveness of a PV Battery System. Energy Procedia 2014, 46, 262-270. [CrossRef]

15. Balcombe, P.; Rigby, D.; Azapagic, A. Energy self-sufficiency, grid demand variability and consumer costs: Integrating solar PV, Stirling engine CHP and battery storage. Appl. Energy 2015, 155, 393-408. [CrossRef]

16. Bianchi, M.; Branchini, L.; De Pascale, A.; Melino, F. Storage Solutions for Renewable Production in Household Sector. Energy Procedia 2014, 61, 242-245. [CrossRef]

17. Seasalt Battery. Available online: http://www.drten.nl/zeezout-batterij/?lang=en (accessed on 5 September 2017).

18. Ciez, R.E.; Whitacre, J.F. The cost of lithium is unlikely to upend the price of Li-ion storage systems. J. Power Sources 2016, 320, 310-313. [CrossRef]

19. Hoogsteen, G.; Molderink, A.; Hurink, J.L.; Smit, G.J.M. Managing energy in time and space in smart grids using TRIANA. IEEE PES Innov. Smart Grid Technol. Conf. Eur. 2015, 1-6. [CrossRef]

20. Perez, K.X.; Baldea, M.; Edgar, T.F.; Hoogsteen, G.; van Leeuwen, R.P.; van der Klauw, T.; Homan, B.; Fink, J.; Smit, G.J.M. Soft-islanding a group of houses through scheduling of CHP, PV and storage. In Proceedings of the 2016 IEEE International Energy Conference (ENERGYCON), Leuven, Belgium, 4-8 April 2016; IEEE: New York, NY, USA, 2016; pp. 1-6. 
21. Gerards, M.E.T.; Toersche, H.A.; Hoogsteen, G.; van der Klauw, T.; Hurink, J.L.; Smit, G.J.M. Demand side management using profile steering. In Proceedings of the 2015 IEEE Eindhoven PowerTech, Eindhoven, The Netherlands, 29 June-2 July 2015; IEEE: New York, NY, USA, 2015; pp. 1-6.

22. Bakker, V.; Molderink, A.; Bosman, M.G.C.; Hurink, J.L.; Smit, G.J.M. On simulating the effect on the energy efficiency of smart grid technologies. In Proceedings of the 2010 Winter Simulation Conference, Baltimore, MD, USA, 5-8 December 2010; IEEE: New York, NY, USA, 2010; pp. 393-404.

23. Pecan Street. Available online: http:/ / www.pecanstreet.org/ (accessed on 8 March 2017).

24. Fares, R.L.; Webber, M.E. Combining a dynamic battery model with high-resolution smart grid data to assess microgrid islanding lifetime. Appl. Energy 2015, 137, 482-489. [CrossRef]

25. Obinna, U.; Joore, P.; Wauben, L.; Reinders, A. Comparison of two residential Smart Grid pilots in the Netherlands and in the USA, focusing on energy performance and user experiences. Appl. Energy 2017, 191, 264-275. [CrossRef]

26. Muralitharan, K.; Sakthivel, R.; Vishnuvarthan, R. Neural Network based Optimization Approach for Energy Demand Prediction in Smart Grid. Neurocomputing 2017. [CrossRef]

27. Van der Klauw, T.; Hoogsteen, G.; Gerards, M.E.T.; Hurink, J.L.; Feng, X.; Hebner, R.E. Assessing the potential of residential HVAC systems for demand-side management. In Proceedings of the 2016 IEEE Power \& Energy Society Innovative Smart Grid Technologies Conference (ISGT), Minneapolis, MN, USA, 6-9 September 2016; IEEE: New York, NY, USA, 2016; pp. 1-5.

28. Hoogsteen, G.; van der Klauw, T.; Molderink, A.; Hurink, J.L.; Smit, G.J.M.; Feng, X.; Hebner, R.E. Balancing islanded residential microgrids using demand side management. In Proceedings of the 2016 IEEE Power \& Energy Society Innovative Smart Grid Technologies Conference (ISGT), Minneapolis, MN, USA, 6-9 September 2016; IEEE: New York, NY, USA, 2016; pp. 1-5.

29. Austin Energy Home. Available online: https:/ / austinenergy.com (accessed on 6 September 2017).

30. Dr Ten Innovatie \& Prestatie. Available online: http://www.energystoragenl.nl/lidbedrijf/dr-ten?lang=en (accessed on 9 September 2017).

31. Holland Trade and Investment Sea-Salt Battery. Available online: https:/ / www.hollandtradeandinvest.com/ showcases/sustainable-dutch-solutions/clean-energy/sea-salt-storage-battery (accessed on 9 September 2017).

32. Ten Kortenaar, M.V. Anodic Oxidation of Formaldehyde on Gold Studied by Electrochemical Impedance Spectroscopy: An Equivalent Circuit Approach. J. Electrochem. Soc. 1999, 146, 2146-2155. [CrossRef]

33. Quintero Pulido, D.; Ten Kortenaar, M.; Hurink, J.; Smit, G. A Practical Approach in Glycerol Oxidation for the Development of A Glycerol Fuel Cell. IMedPub J. Trends Green Chem. 2017, 3, 1-17.

34. Hoogsteen, G. A Cyber-Physical Systems Perspective on Decentralized Energy Management; University of Twente: Enschede, The Netherlands, 2017.

35. Spiers, D. Batteries in PV Systems. In McEvoy's Handbook of Photovoltaics; Elsevier: Amsterdam, The Netherlands, 2018; pp. 789-843, ISBN 9780128099216.

36. Affordable Solar Off-Grid System Sizing-Affordable Solar. Available online: http:/ / www.affordable-solar. com/learning-center/solar-basics/off-grid-system-sizing/ (accessed on 27 December 2017).

(C) 2018 by the authors. Licensee MDPI, Basel, Switzerland. This article is an open access article distributed under the terms and conditions of the Creative Commons Attribution (CC BY) license (http:// creativecommons.org/licenses/by/4.0/). 